\title{
THE INFLUENCE OF INTELLECTUAL CAPITAL ON ROMANIAN COMPANIES' FINANCIAL PERFORMANCE
}

\author{
Claudiu-Marian Gruian ${ }^{1}$
}

\begin{abstract}
This article aims to theoretically and empirically argue the influence of intellectual capital on financial performance at microeconomic level. Based on data collected from the financial statements of companies listed at Bucharest Stock Exchange, present study analyses the correlation between intellectual capital and its components, calculated by using the VAIC method, and financial performance, calculated by using Return on Equity. Several regression models are being used. The results support the proposed hypothesis, proving that there is a significant positive correlation between intellectual capital and financial performance. By extrapolating it can be said that the role of intellectual capital is important in achieving competitive advantages by companies from emerging economies where performance is usually strongly determined by the physical capital employed
\end{abstract}

Key words: intellectual capital, financial performance, value added intellectual coefficient, Bucharest Stock Exchange

JEL Codes: D24, L25

\section{Introduction}

In the knowledge based economy intellectual capital (IC) is considered the key factor influencing business performance. Many theoretical and empirical studies confirm its strong effect on the overall results of the firm. However IC can not exist without human capital; witch is in fact its main component.

In transition economies, because of the imperfections of the labor market, staff costs are not always correlated with productivity. Thus in some cases wages may be influenced or even set by employers and employees may be forced to accept the situation due to the lack of alternative job offers. On the other hand an opposite situation can occur especially in large companies with strong trade unions that have the power to raise salaries more than productivity growth. Other imperfections may appear in state owned companies and in the public sector where sometimes discriminations are made in the recruitment process due to political orientation and other individual and group interests of executives.

Considering the labor market imperfections presented above there are some doubts about the positive effect of IC on companies' performance in emergent countries. Based on empirical research present paper tries to confirm the positive and significant influence that intellectual capital has on Romanian companies' performance, especially from the financial point of view in spite of the imperfections in the labor market. As the majority of studies show, this correlation exists especially in developed countries, that have preponderantly knowledge based economies. However this study will try to confirm the fact that the correlation also exists in emergent economies and it is growing stronger over time. The empirical study that will try to validate these assumptions uses the Value Adder Intellectual Coefficient (VAIC) methodology and data from a sample of companies listed on the Bucharest Stock Exchange.

\footnotetext{
${ }^{1}$ West University of Timisoara, Faculty of Economics and Business Administration, J.H. Pestalozzi, nr. 16, Timisoara, claudiu_gruian@hotmail.com
} 
The paper is structured in four sections. The first presents a short literature review regarding the concepts of IC and financial performance, their measurement and correlation. Second section presents the proposed research methodology. In the third section study results are present and discussed and in the last part of the paper several conclusions are being drawn.

\section{Literature review and hypotheses}

Before moving to IC measurement and verifying the correlation between it and the financial performance of the company we must first understand what IC is and how it is measured. Some clarifications are required because at the moment a unique way of defining and measuring IC doesn't exist. In practice there are several widely accepted and used methods that offer numerous advantages.

In literature there are several approaches to IC. The first author who uses this term is Kenneth Galbraith in 1969 (Bontis, 1998: 67) in the sense of employees knowledge put into practice. This means that knowledge has no value per se, but only if it is actually used. It is necessary to delimit the concepts knowledge and information. Thus we can say that information is the raw material and knowledge is the finished product. The information presents particular circumstances and facts. On the other hand knowledge presents general characteristics and phenomena. A well-known expression shows in a very suggestive way the difficulties that researchers and practitioners encountered in understanding the essence of IC. Bontis (1998) presents this factor to be: considered by many, defined by some, understood by a select few and valued by practically no one.

In Thomas Stewart's (1998) point of view IC consists in knowledge owned by employees and knowledge built in equipment and networks that participate in the production process. Nowadays the proportion of intangible production factors consumed by companies is in a continuous growth. The Indian author C. Srinivasan (2004) states that the IC of a company includes two components: (1) basic knowledge of the organization, which are incorporated in all activities and (2) knowledge and values of individual employees. The same author assessed that about $42 \%$ of the IC is in the minds of employees and the economic benefits of that capital represent only a relatively small extent. IC has certain characteristics that underlie its impressive ability to create value added. It can leverage other resources at micro and macroeconomic level, since it can replace a part of the expenses and the handling and transportation difficulties of other physical factors thus enhancing business revenue.

Formerly, for locating companies we ware talking about halls and stores (i.e. physical assets), now things have changed. Many types of business: advertising agencies, consulting firms, service companies, design centers, travel agencies, computer companies, companies engaged in online commerce, and others have very few physical assets. They are mostly known by their trademark. Within these companies, the predominant share of expenditure is represented by intangible assets. As a result, expenses structure has changed. Elements like salaries and training of specialists, research and development, processes treatment, knowledge management and marketing have greater weight in total expenditures.

IC value and its ability to produce value added depend on the skills and motivation level of people involved in its use. Unlike other forms of capital it has a strong human and managerial determination. Same knowledge put into practice in different human and managerial contexts will practically have different value and will generate different amounts of value added. From this point of view, IC resembles human capital, with whom it is, in fact, closely connected. Consequently, these factors should be considered a priority in the use of IC. After analyzing the approaches of several important authors Suciu (2006: 90) reached three conclusions: (1) IC is an intangible resource of the company, (2) competitive advantage is based on IC, and (3) company value is the result of intellectual capital leverage. The same author defines IC as the sum of all company's 
intangible resources that confer a competitive advantage and which combined, could bring future benefits.

Over time authors identified three distinct components of IC: human capital, structural capital and relational (customer) capital. This classification has enjoyed a wide acceptance (Clarke, et al. 2010: 4). Other authors have identified only two components: individual employees' knowledge and structural capital, which is what remains within the company after the employees leave work.

Human Capital (HC) refers to the knowledge, skills and abilities of employees, i.e. professionalism, efficiency and effectiveness in improving business productivity. HC is the first component to be identified by researchers. The two categories are even sometimes confused. For example, Ulrich (1998) argues that IC is the product of employees' competence and loyalty. However, IC is not limited to human capital but it can be said that at employee level IC consists of education, professionalism and dedication.

Structural capital (SC) is a component of IC formed within the company and consists of specific policies, procedures, processes, working environment, all information and know-how, whatever their nature - technology (patents, trademarks, designs), economic (information on market prices, credit, taxes), legal (laws, ordinances and other laws relating to company), management system.

Relational or customer capital refers to the relations built between the company and third parties among the most important ones refer to suppliers and customers. Relations are based on collaboration and mutual trust and present advantages both for the company and business partners.

\section{Intellectual capital measurement}

Considering the intangible nature of the IC, its measurement is difficult. As a consequence researchers and practitioners developed several valuation methods. They can be grouped according to the nature of the information used in valuation as follows: (1) methods based on market capitalization: Tobin's Q for example; (2) methods based on the return on capital employed: Market Value Added and Economic Value Added (3) methods based on scoring: Skandia Navigator, Balanced Scorecard, IC Index; (4) methods based on direct calculation of IC: Technology Broker, Inclusive Valuation Methodology; (5) methods based on value added: the Value Added Intellectual Coefficient, and others.

Skandia Navigator is the generic name of the first model of IC management and valuation. The name belongs to Skandia, the first financial service company to consider the importance of knowledge management and create a model for IC evaluation and development. The same company was the first to prepare a written report regarding the intangible resources of the company, and to present it to its shareholders along with the annual financial statements. The main initiator of Skandia Navigator was Leif Edvinsson, worlds first Chief Knowledge Officer. The model focuses on five important areas: financial, customers, processes, human resources renewal and development. It has been appreciated and implemented later by other large companies. The main achievement of Skandia Navigator is the proposed taxonomy for the IC components. This includes an impressive number of indicators for each one of the five covered areas, totally 112.

IC Index is an integrated valuation model that reunites individual indicators of IC components. It facilitates longitudinal and transversal comparisons within and between companies, and correlation analysis considering the influence of IC on performance, market value and other indicators. Yet to insure IC Index comparability, its structure and the relative weight of its individual indicators must be maintained constant. This is often difficult to achieve for all companies and sectors because certain indicators are more important to some activities than others.

Technology broker is a model developed by Annie Brooking, based on the way IC is being defined. She identifies four important components in IC analysis: market assets, human centered assets, intellectual property assets and infrastructure assets. The four components are being valuated 
using detailed questionnaires. A measurement of IC can be made based on the questionnaire results by utilizing one of the three proposed approaches: cost reduction, market value growth and profit growth generated by IC utilization.

Market Value Added is the difference between the capital invested in the company by the shareholders (shareholders equity) and the cash that they could get by selling their equity at that moment. The invested capital includes the amount provided at the beginning of the business and the profit left at company's disposal over the years. Most authors that start their research on IC argue that it is the value of the company that is missing from its financial statements. In other words they consider it to be the difference between the market value and the book value of the company. From this point of view, market value added seems to be the best and easiest way to calculate IC value. In spite of the mentioned advantages this method is rarely used because the market value of companies is often influenced by other factors that have nothing to do with IC: former company performance, financial market evolution, economic cycles and others.

Economic Value Added is a measurement method used for IC valuation and performance management. It brings certain improvements comparing to Market Value Added. One of its advantages is the fact that the opportunity cost of the invested capital is taken into consideration. Thus a company in considered to be performing only if its profit overcomes the average market cost of capital. Like Market Value Added, Economic Value Added is a measure of IC that has the characteristics of a black box, because it only measures the results of IC utilization and doesn't show its components or their contribution to company performance.

Another measure of IC that can be obtained relatively easy and used in many empirical studies is the Value Added Intellectual Coefficient (VAIC), created and developed by A. Pulic (1998). This method uses public audited accounting data. VAIC shows the value creation efficiency of the resources used by the company (physical, human and structural capital employed). Its main indicator is Value Added. According to VAIC methodology the more qualitative the resources the more effective the value creation process.

\section{Company's financial performance}

Current studies identify two important elements of performance that are analyzed in detail in literature: financial and non-financial performance. Analysis of the former is usually based on the information contained in the Annual Financial Statements. The second concerns the quality aspects of the business related to the quality of corporate governance, management, IC and others.

Company's financial performance is the natural consequence of operational performance, understood as the final result of all corporate efforts. If the other dimensions related to performance (productivity, efficiency, effectiveness) show measurement difficulties, these disappear in the case of financial performance, which is a global measure of all the others. Much of the empirical studies that examine financial performance are limited to an analysis based on accounting information because it can be obtained and compared easily.

Financial performance is a measure of how well a company uses the invested capital to generate income. This term is usually utilized as a measure of the overall health of the company for a certain period of time, and can be used to compare similar entities in the same industry or to compare industries and sectors. Generally speaking there are currently two categories of methods for measuring financial performance: methods based on the analysis of accounting information and methods based on market value. Performance analysis based on accounting measures uses the annual financial statements as source of information. On this basis there are calculated a series of financial ratios covering several quantitative and qualitative aspects of performance: profitability, liquidity, financial structure (debt) and turnover.

It is often said that the most important outcome of the activity is, in terms of company owners, the profit. This is only partially true. For example, owners will not be satisfied if the company achieves higher revenues than expenses but doesn't have cash to repay them with 
dividends. Companies can also report high profits, and at the same time have to pay large debts in the future. In other cases profit is high but isn't distributed to shareholders. Therefore accounting profit is not synonymous with financial performance. On these grounds it is advisable consider all categories of performance indicators (rates of return, leverage, liquidity and cash-flows) to have an overview on business health and prospects.

In the accounting sense and according to the international accounting and financial reporting standards (International Accounting Standards - IAS, International Financial Reporting Standards IFRS), financial performance refers to the revenues, expenditures and financial results (profit or loss) of an economic entity (Achim, 2010: 322). So in this category all data available from company's Income Statement is included. Therefore accounting standards present a broader vision, as they include both financial results and their determinant elements (revenues and expenditure) in the financial performance indicators category. In conclusion, financial performance is usually what matters the most, primarily for the company owners (directly) and secondly for all stakeholders (indirectly). Achieving good financial results is therefore a key objective of any company.

\section{The influence of intellectual capital on company's financial performance}

Renowned field authors like Nick Bontis, head of the Intellectual Capital Research Institute, present in their theoretical and empirical work (Bontis et al, 1999; Bontis, 2001) the significant influence of IC on business performance regardless the field of activity. Numerous studies show that IC is also one of the main factors determining the market value of listed companies. In the last two decades we can see strong upward trends of listed companies' market value while the net asset value has not changed significantly (Ciobanu, 2006: 135).

Empirical studies that test the correlation between IC and company performance are varied. They differ, in particular, depending on the method used to measure IC. Most studies have shown a positive correlation between the two (Clarke et al. 2010: 6). Choi and Whang (2009) verified the influence of relational capital (quality of relations between the company and non-financial stakeholders: employees, customers, suppliers and community) on company performance and concluded that good cooperation relations have a significant positive effect, especially for companies that encountered difficulties and are undergoing recovery. Riahi-Belkaoui (2003) identified a positive correlation between IC and company financial performance. Similar results were obtained by Chen et al. (2005). Their study concluded that IC strongly influences profitability. However not all studies have found correlations between the two variables. Thus Firer and Williams (2003) have identified an insignificant relationship, as well as Maditinos et al. (2011), authors that identified a significant link only between human capital efficiency and economic profitability of companies (measured by Return on Assets).

Given the various results obtained in the former studies and considering the importance of theory empirical verification, further studies are necessary for supporting and explaining the relationship between the two variables and to identify the circumstances that gave rise to obtaining different results in the previous studies. This paper will attempt to empirically verify the following hypotheses:

Primary hypothesis:

1a, b. Companies with greater IC have better financial performance

Secondary hypotheses:

2a. Companies with greater capital employed efficiency have better financial performance

2b. Companies with greater human capital efficiency have better financial performance

2c. Companies with greater structural capital efficiency have better financial performance 


\section{Research methodology}

The sample used in this study is composed of 41 non-financial companies from Romania listed on the Bucharest Stock Exchange (BSE) quoted at $1^{\text {st }}, 2^{\text {nd }}$ and $3^{\text {rd }}$ category. Companies belong to the following sectors (CAEN. national classification 2, adapted from the statistic classification used in the European community NACE Rev.2): Mining - 3 companies, Manufacturing - 27 companies, Utilities - 1 company, Construction - 3 companies, Commerce: 2 companies, Transport and Storage - 3 Companies, Hotels and Restaurants - 2 companies. The 41 companies are mentioned in Appendix 1. The collected data corresponds to a period of three years: 2007-2009. The original target sample consisted of all 62 non-financial companies listed on BSE's main square but in the data collecting process it was found that certain information was not available for the entire period. In other words some companies did not provide all necessary data to calculate the independent variables used in the study. Another obstacle in data collection was the various form of financial results disclosure. The only sources of data considered were the Individual Annual Financial Statements certified by external auditors, more precisely the Balance Sheet and the Income Statement (Profit and Loss Account). The statements were obtained from companies' websites, and the official website of BSE. Therefore 21 companies were excluded from the study only due to insufficient data. However the 41 companies remaining in the study represent $66.13 \%$ of the total non-financial companies listed on BSE in 2011.

This study considers several independent variables corresponding with the method used for IC measurement. Thus the Value Added Intellectual Coefficient (VAIC), a method used recently by many other authors (Maditinos et al., 2011; Zeghal and Maaloul, 2010, Muhammad and Ismail, 2009) involves determining the following independent variables:

1. Capital Employed Efficiency (CEE) - shows the company's ability to create value added in relation to its permanent capital. CEE is determined by reporting value added (VA) to capital employed (CE):

$$
\mathrm{CEE}=\mathrm{VA} / \mathrm{CE}
$$

Value added is calculated as difference between the outputs and inputs of the production process. We consider outputs all operational revenues except the category entitled other operational revenues. We consider inputs all external expenses. This calculation methodology is chosen because it is more practical. The data collection process is easier for the fact that the information is presented on consecutive rows in the Income Statement.

Employed capital represents the permanent capital of the company and it includes shareholders equity and long term liabilities. We can find this indicator in company's Balance Sheet as total assets minus current liabilities.

2. Human Capital Efficiency (HCE) - indicates the efficiency with which employees participate in creating value added in the company and is calculated as the ratio between value added and the cost of human capital (HC):

$$
\mathrm{HCE}=\mathrm{VA} / \mathrm{HC}
$$

$\mathrm{HC}$ is the company's total staff expenditure, including expenditure on employee health and social security.

3. Structural Capital Efficiency (SCE) - reflects the participation of structural capital in the creation of value added and it is calculated as the ratio between structural capital (SC) and value added:

$$
\mathrm{SCE}=\mathrm{SC} / \mathrm{VA}
$$


Structural capital is determined as the difference between value added and staff expenses.

4. Value Added Intellectual Coefficient (VAIC) is calculated by summing the three efficiency items above:

$$
\mathrm{VAIC}=\mathrm{CEE}+\mathrm{HCE}+\mathrm{SCE} \quad \text { (4) }
$$

All variables were calculated for each company and each year and then a three year average was approximated (2007-2009).

This intellectual capital valuation method (VAIC) has many advantages such as:

- High relevance of intellectual capital calculation (Pulic, 1998, Bontis et al., 1999);

- Ease of use;

- The data used are relatively easy to obtain and sources are reliable;

- Allows comparative studies.

The study considers as dependent variable Return on Equity (ROE) because it is widely used in literature to describe company's financial performance. ROE is determined by dividing net profit to all capitals invested in the company by shareholders directly (through a capital contribution) and indirectly (through profits reinvestment approval) which is actually the company's equity.

\section{ROE $=$ Net Profit / Shareholders Equity}

After calculating ROE for each of the three years an average value was determined for every company. Financial performance can be sometimes diminished by company management for carrying out investments and making other necessary or desirable expenses for the growth of the company. Exceptional expenses that affect profitability may also occur. This is why it is more relevant to consider a three year average ROE that is not influenced so much of conjecture.

For examining the correlation between intellectual capital and financial performance we chose a simple and a multiple linear regression. The regression results were obtained using Microsoft Excel 2003 Data Analysis Pak.

For validating the main hypothesis we considered the influence of the Value Added Intellectual Coefficient (VAIC) which is calculated by summing its three components. We also considered the possibility that some of VAIC's components have a greater influence on financial performance than others. So we also build a multiple linear regression containing the three IC components, to check which one is more important in achieving high financial performance.

For verifying the primary hypothesis we used the following regression models:

Model 1a: $\mathrm{ROE}=\mathrm{a}_{0}+\mathrm{a}_{1} \mathrm{VAIC}+\mathrm{e}$

Model 1b: ROE $=b_{0}+b_{1} C E E+b_{2} \mathrm{HCE}+b_{3} \mathrm{SCE}+\mathrm{e}$

For verifying the secondary hypotheses we used:

Model 2a: $\mathrm{ROE}=\mathrm{a}_{0}+\mathrm{a}_{1} \mathrm{CEE}+\mathrm{e}$

Model 2b: $\mathrm{ROE}=\mathrm{b}_{0}+\mathrm{b}_{1} \mathrm{HCE}+\mathrm{e}$

Model 2c: $\mathrm{ROE}=\mathrm{c}_{0}+\mathrm{c}_{1} \mathrm{SCE}+\mathrm{e}$

\section{Study results}

Descriptive statistics for all study variables is presented in Table 1. The statistical data analysis provides sufficient data to draw a few conclusions. As a complementary conclusion we can observe a very low average for the financial performance of companies in the sample (only 3.6\%). By comparing the results with those of a recent study on a sample of companies in Greece (Maditinos et al., 2011) we note that the average ROE indicator is about 3.4 times lower for the Romanian companies. Also the other indicators designed for IC valuation are lower. The main explanation of these results can be considered the lower competitiveness of Romanian economy and the different period analyzed, considering that the present study includes a more recent period 
(2007-2009, compared to 2006-2008 - Greek study) and the negative effects of the global economic and financial crisis are stronger.

Table no. 1

Descriptive statistics for study variables

\begin{tabular}{|c|c|c|c|c|}
\hline Variable & Mean & $\begin{array}{c}\text { Standard } \\
\text { Deviation }\end{array}$ & Minimum & Maximum \\
\hline ROE & 0.036 & 0.099 & -0.287 & 0.234 \\
\hline VAIC & 2.713 & 0.939 & -0.309 & 5.111 \\
\hline CEE & 0.373 & 0.268 & 0.024 & 1.593 \\
\hline HCC & 1.961 & 0.757 & 0.656 & 4.586 \\
\hline SCE & 0.379 & 0.356 & -1.435 & 1.043 \\
\hline
\end{tabular}

Source: author's calculations based on BSE companies' financial statements

Correlation and determination coefficients for all the regressions built are presented in Table 2. The significance of regression results is presented as follows: Tables 3 (Model 1a) and 4 (Model 1b) for the primary hypothesis and Table 5 for the secondary hypotheses (Models 2a, 2b and 2c).

As we can see in Table 2 several correlations exist between the independent variables and ROE. Thus financial performance is correlated with Value Added Intellectual Coefficient; the correlation coefficient is about 0.355 . Although the correlation is relatively weak, it is considered significant, given the fact that the upper critical value in Pearson's Table for a number of 41 observations and a 95\% probability level, accepted in academia, is 0.308 . Therefore the study results support the main hypothesis. Nevertheless the determination coefficient is quite low (0.104) showing that the influence of IC represents only $10 \%$ of companies' financial performance.

Table no. 2

Correlation analysis

\begin{tabular}{|c|c|c|c||}
\hline Regression models & $\begin{array}{c}\text { Pearson's } \\
\text { coefficient }\end{array}$ & Adjusted R $^{2}$ & Significance (p*) $^{*}$ \\
\hline Model 1a: ROE \& VAIC & 0.355 & 0.104 & 0.023 \\
\hline $\begin{array}{c}\text { Model 1b: } \\
\text { ROE \& CEE, HCE, SCE }\end{array}$ & 0.590 & 0.297 & 0.001 \\
\hline Model 2a: ROE \& CEE & 0.436 & 0.170 & 0.004 \\
\hline Model 2b: ROE \& HCE & 0.199 & 0.016 & 0.212 \\
\hline Model 2c: ROE \& SCE & 0.185 & 0.010 & 0.247 \\
\hline
\end{tabular}

* Significant when smaller than 0.05

Source: author's calculations based on BSE companies' financial statements

The relative influence of VAIC structural components (hypothesis1b and model $1 \mathrm{~b}$ ) is also significant. The correlation coefficient is even higher than the one in Model 1a, proving that the introduction of such a model was inspired. The adjusted determination coefficient shows that near $30 \%$ of companie's financial performance is influenced by IC components. Therefore it is verified that VAIC components have a weighted influence on financial performance. 
Table no. 3

Regression results - Model 1a: ROE and VAIC

\begin{tabular}{||c|c|c|c|c|c|}
\hline $\begin{array}{c}\text { Independent } \\
\text { variable }\end{array}$ & Coefficient & $\begin{array}{c}\text { Standard } \\
\text { Error }\end{array}$ & $\mathbf{t}$ - stat & Significance & Adjusted R $\mathbf{R}^{\mathbf{2}}$ \\
\hline Constant & -0.065 & 0.045 & -1.442 & 0.157 & \multirow{2}{*}{0,104} \\
\hline$V A I C$ & 0.037 & 0.016 & 2.372 & 0.023 & \\
\hline
\end{tabular}

Source: author's calculations based on BSE companies' financial statements

The third regression model (Model 2a) has similar results with the former, supporting the correlation between the efficiency of capital employed and company's financial performance. The correlation is not very strong but in this case is significant for the number of observations made. Yet the results did not verify hypotheses $2 b$ and $2 c$. The correlation coefficients are also positive in their case, but their values are insignificant.

Regression results - Model 1b: ROE VAIC components

\begin{tabular}{|l|c|c|c|c|c|}
\hline $\begin{array}{c}\text { Independent } \\
\text { variables }\end{array}$ & Coefficient & $\begin{array}{c}\text { Standard } \\
\text { Error }\end{array}$ & t - stat & Significance & Adjusted R \\
\cline { 1 - 5 } Constant & -0.142 & 0.049 & -2.920 & 0.006 & \\
\cline { 1 - 3 } & 0.216 & 0.052 & 4.134 & 0.000 & \multirow{2}{*}{0,297} \\
\cline { 1 - 2 } & 0.041 & 0.022 & 1.918 & 0.063 & \\
\hline SCE & 0.043 & 0.044 & 0.969 & 0.339 & \\
\hline
\end{tabular}

Source: author's calculations based on BSE companies' financial statements

Data in Table 3 confirms that the main hypothesis of the study is true because the correlation is significant ( $\mathrm{p}$ <.05). The results of Model 1b (Table 4) show the relative influence of each of the VAIC components on financial performance. We can observe the strong influence that capital employed efficiency has on ROE. The influence of the other two components (human and structural capital) is insignificant ( $\mathrm{p}>.05)$. Yet it is noted that human capital efficiency has a significance very close to the critical value $(0.063)$ but still unacceptable.

Table no.5

Regression results - Models 2a, $2 b$ and $2 c$

\begin{tabular}{|c|c|c|c|c|c|c|}
\hline \multicolumn{2}{|c|}{ Independent variables } & Coefficient & Standard & t - stat & Significance & Adjusted $\mathbf{R}^{2}$ \\
\hline Model 2a & $\begin{array}{l}\text { Constant } \\
C E E\end{array}$ & $\begin{array}{c}-0.024 \\
0.16\end{array}$ & $\begin{array}{l}0.024 \\
0.053\end{array}$ & $\begin{array}{c}-0.973 \\
3.028 \\
\end{array}$ & $\begin{array}{l}0.336 \\
0.004\end{array}$ & 0,170 \\
\hline Model 2b & $\begin{array}{l}\text { Constant } \\
\text { HCE }\end{array}$ & $\begin{array}{l}-0.015 \\
0.026 \\
\end{array}$ & $\begin{array}{c}0.043 \\
0.02 \\
\end{array}$ & $\begin{array}{c}-0.341 \\
1.268 \\
\end{array}$ & $\begin{array}{l}0.735 \\
0.212 \\
\end{array}$ & 0,016 \\
\hline Model 2c & $\begin{array}{l}\text { Constant } \\
\text { SCE }\end{array}$ & $\begin{array}{l}0.017 \\
0.051\end{array}$ & $\begin{array}{l}0.023 \\
0.044\end{array}$ & $\begin{array}{l}0.741 \\
1.177\end{array}$ & $\begin{array}{l}0.463 \\
0.247\end{array}$ & 0,010 \\
\hline
\end{tabular}

Source: author's calculations based on BSE companies' financial statements

Models $2 \mathrm{a}, 2 \mathrm{~b}$ and $2 \mathrm{c}$ confirm that employed capital efficiency is the main factor influencing financial performance, because it is the only indicator correlated to ROE. The coefficients obtained for the correlation between the efficiency of human capital and structural capital, are insignificant for the sample. Therefore hypothesis $1 \mathrm{a}$ is proved to be true, but hypotheses $2 \mathrm{~b}$ and $2 \mathrm{c}$ are not 
supported by the empirical results obtained. In conclusion, the main hypothesis is empirically proven and results are within acceptable limits. Financial performance is therefore influenced by the IC, and companies with that add greater value are generally more profitable.

\section{Discussion}

In general, studies that use the VAIC methodology have mixed and even contradictory findings. The results obtained in this study should therefore be compared with those obtained by other researchers who have used the same methods.

Much of the published empirical studies confirm the correlation between the two variables in this study (IC and ROE). Chen et al. (2005) in a broader study on a sample of companies from Taiwan obtained positive results, supporting the influence of intellectual capital on financial performance measured by ROE. In their study performance is also strongly determined by the capital employed efficiency (CEE). IC's positive influence on profitability is also validated by Gan and Saleh (2008), researchers who analyzed a sample of high-tech companies listed at Malaysia Stock Exchange. Again profitability has been proved to be strongly determined by the physical capital employed. Other authors had similar results (Shiu, 2006; Ahangar, 2011).

A significant number of researches do not confirm the correlation between two variables. Najibullah (2005), following a study based on data from several banks listed on the local stock exchange in Bangladesh concluded that there is no significant correlation between the IC and ROE. However his study verifies the correlation between financial performance and capital employed efficiency. Firer and Williams (2003) after analyzing a sample of 75 companies in South Africa concluded that there is no correlation between IC and profitability.

Differences between the various research results can have many causes. Financial performance is influenced by a variety of factors but IC is only one of them. Therefore the positive influence of IC can be countered by the negative influence of other factors. Financial performance also reflects the result of all company activities: operational, financial and extraordinary. IC only affects the operational activity. Hence the two measures do not have the same coverage. For firms that have significant payable interests on loans contracted earlier, the positive use of the IC can be reduced by these financial costs.

Although some studies confirm the correlation between variables and others do not, research results are often close. Thus most studies confirm the link, but do so under relatively low correlation coefficients, as it is in the present case $(0.355)$. On the other hand studies with insignificant results have correlation coefficients close to the critical value, but inferior. It is also noticed that all studies have positive correlation coefficients, so the assumption that IC would have a negative influence on financial performance is proved to be invalid.

\section{Conclusions, limitations and future research}

Present study is the first to assess the intellectual capital of companies listed at the Bucharest Stock Exchange and one of the few empirical approaches IC in the domestic literature. The results are original and valuable in at least two ways. First because it validates the significant positive influence that intellectual capital has on financial performance, in the case of non-financial companies listed on Bucharest Stock Exchange. Second, because it validates VAIC model's ability to assess corporate intellectual capital. This paper enriches the research literature with another study that confirms the positive influence of intellectual capital on corporate performance. From the results obtained we also emphasize that for the observed companies, the efficiency of capital employed to generate value added is the main factor that influences performance. The Influence of human and structural capital, however, is not very strong. A possible explanation is the fact that at BSE there still are companies undergoing reorganization, and in some of them the Romanian government is still a shareholder. For these reasons, high human capital costs do not have the desired leverage on value added and financial performance. 
From this research we can also draw some conclusions that are not related to the actual results of the study. Thus it was found that some companies, in spite of the fact that they are listed on the Bucharest Stock Exchange, do not disclose sufficient information to investors, researchers and other categories of stakeholders who are interested to develop an analysis of this kind, or the information is presented in various forms and it is often difficult to collect. Therefore an improvement is recommended in the way that companies report their financial results. Foremost the obligation to present annual financial statements, corresponding to local legal regulations, for the former 3-5 years should be introduced.

This study has some limitations. They are related on the one hand to the model used for valuating intellectual capital (VAIC) and on the other hand to the sample of companies and the used methodology. VAIC model weaknesses are detailed in literature and it is not necessary to present them here. In the second category we can mention the relatively small number of non financial companies entering the study, which cover a limited number of sectors. Another negative aspect that can be considered is the relatively low period of analysis (2007-2009). In addition, in the last two years of analysis (2008 and 2009) Romanian companies have suffered the imprint of the economic and financial crisis; which has adversely affected their financial performance.

To limit some of the shortcomings future studies should try using different indicators to measure financial performance. These indicators should be based on operational results (because they are not affected by the financial policy of the company) and could use capital employed as a denominator, because it is the same indicator used in the VAIC model. Future studies could also Include companies from all economic sectors and compare the amount of value added intellectual in each sector.

Although non-financial Romanian company's performance is still strongly based on physical capital employed efficiency, the influence of intellectual capital exists, and generates a leverage effect on value added and financial performance. Therefore managers and company owners should consider this important factor that may confer a decisive advantage in the market competition.

\section{References}

1. Achim M.V., 2010. Analiză economico-financiară, Cluj-Napoca, Risoprint Publishing

2. Ahangar R.G., 2011. The relationship between intellectual capital and financial performance: an empirical investigation in an Iranian company, African Journal of Business Management, Vol. 5, No. 1, pp. 88-95

3. Bontis N., 1998. Intellectual capital: an exploratory study that develops measures and models, Management Decision, Vol. 36, No. 2, pp. 63-76

4. Bontis N., 2001. Assessing knowledge assets: a review of the models used to measure intellectual capital, International Journal of Management Reviews, Vol. 3, Issue 1, pp. 41-60

5. Bontis N., Dragonetti N.C., Jacobsen K., Ross G., 1999. The knowledge toolbox: a review of the tools available to measure and manage intangible resources, European Management Journal, Vol. 17, No. 4, pp. 391-402

6. Chen M.C., Cheng S.J., Hwang Y., 2005. An empirical investigation on the relationship between intellectual capital and firm's market value and financial performance, Journal of Intellectual Capital, Vol. 6, No. 2, pp. 159-176

7. Choi J., Wang H., 2009. Research notes and commentaries. Stakeholder relations and the persistence of corporate financial performance, Strategic Management Journal, No. 30, pp. 895-907

8. Ciobanu A., 2006. Analiza performanței întreprinderii, Bucharest, ASE Publishing 
9. Clarke M., Seng D., Whiting H., 2010. Intellectual capital and firm performance in Australia, Working Paper series no. 12, University of Otago, New Zealand, available at: http://eprints.otago.ac.nz/927/1/Working_paper_Clarke-Seng-Whiting-revised.pdf, accessed 10 February, 2011

10. Firer S., Williams S.M., 2003. Intellectual capital and traditional measures of corporate performance, Journal of Intellectual Capital, Vol. 4, Issue 3, pp. 348-260

11. Gan K., Saleh Z., 2008. Intellectual capital and corporate performance of technologyintensive companies: Malaysia evidence, Asian Journal of Business and Accounting, Vol. 1, Issue 1, pp. 113-130

12. Maditinos D., Chatzoudes D., Tsairidis C., Theriou G., 2011. The impact of intellectual capital on firm's market value and financial performance, Journal of Intellectual Capital, Vol. 12, No. 1, pp. 132-151

13. Muhammad N.M.K., Ismail M.K.A., 2009. Intellectual capital efficiency and firm's performance: study on Malaysian financial sectors, International Journal of Economics and Finance, Vol. 1, No. 2, pp. 206-212

14. Najibullah S., 2005. An empirical investigation of the relationship between intellectual capital and firm's market value and financial performance in the context of commercial banks of Bangladesh, Working Paper, Independent University of Bangladesh, available at http://sb.iub.edu.bd/internship/autumn2005/0220175.pdf accessed 10 February, 2011

15. Pulic A., 1998. Measuring the performance of intellectual potential in knowledge economy, available on-line at http://www.vaic-on.net/download/Papers, accessed 19 January, 2011

16. Riahi-Belkaoui A., 2003. Intellectual capital and firm performance of US multinational firms: A study of the resource-based and stakeholder views, Journal of Intellectual Capital, Vol. 4, No. 2, pp.215-226

17. Shiu H., 2006. The application of the Value Added Intellectual Coefficient to measure Corporate performance: evidence from technological firms, International Journal of Management, Vol. 23, No. 2, pp. 356-365

18. Srinivasan C., 2004. Productivity in the e-Age, Tokyo, APO

19. Stewart, T.A., 1998. Intellectual Capital: The New Wealth of Organizations, London, Nicholas Brealey Publishing House

20. Suciu C., 2006. Intellectual capital as a source of the competitive advantage, Management \& Marketing, No. 4, pp. 89-94

21. Ulrich D., 1998. Intellectual capital = competence $\mathrm{x}$ commitment, Sloan Management Review, Vol. 39, No. 2, pp. 15-26

22. Zeghal D., Maaloul A., 2010. Analyzing value added as an indicator of intellectual capital and its consequences on company performance, Journal of Intellectual Capital, Vol. 11, No. 1, pp. 39-60 
Appendix 1 Values obtained for empirical study variables

\begin{tabular}{|c|c|c|c|c|c|}
\hline $\begin{array}{l}\text { Bucharest Stock } \\
\text { Exchange Symbol }\end{array}$ & ROE* & $\underset{*}{\mathbf{C E E}}$ & HCA* & SCE* & VAIC* \\
\hline$\overline{\mathrm{ALU}}$ & $18,68 \%$ & 0,4786 & 2,6212 & 0,6139 & 3,7137 \\
\hline ARS & $14,21 \%$ & 0,9152 & 1,3518 & 0,2543 & 2,5213 \\
\hline ART & $-13,30 \%$ & 0,2300 & 2,1530 & 0,5196 & 2,9025 \\
\hline ATB & $7,46 \%$ & 0,4219 & 1,8133 & 0,4463 & 2,6815 \\
\hline $\mathrm{AZO}$ & $10,54 \%$ & 0,3656 & 2,1014 & 0,2818 & 2,7488 \\
\hline $\mathrm{BIO}$ & $2,32 \%$ & 0,2325 & 2,6161 & 0,6171 & 3,4657 \\
\hline $\mathrm{CBC}$ & $0,59 \%$ & 0,2342 & 1,3460 & 0,2568 & 1,8370 \\
\hline CEON & $11,93 \%$ & 0,2471 & 2,4765 & 0,5937 & 3,3172 \\
\hline CGC & $2,81 \%$ & 0,3262 & 1,9152 & 0,4732 & 2,7145 \\
\hline CMP & $1,04 \%$ & 0,2587 & 1,8804 & 0,4570 & 2,5961 \\
\hline COMI & $11,85 \%$ & 0,4411 & 1,5324 & 0,3438 & 2,3173 \\
\hline COS & $-1,21 \%$ & 0,4617 & 1,5421 & $-0,2402$ & 1,7636 \\
\hline COTR & $10,14 \%$ & 0,2908 & 2,0728 & 0,5120 & 2,8756 \\
\hline DAFR & $4,00 \%$ & 0,2693 & 2,0441 & 0,5108 & 2,8242 \\
\hline EFO & $3,31 \%$ & 0,0583 & 1,7753 & 0,4341 & 2,2676 \\
\hline ELGS & $23,42 \%$ & 1,5932 & 1,3330 & 0,2454 & 3,1716 \\
\hline IMP & $1,59 \%$ & 0,0463 & 4,5863 & 0,4789 & 5,1114 \\
\hline $\mathrm{MECF}$ & $-10,91 \%$ & 0,2627 & 1,7908 & 0,4301 & 2,4836 \\
\hline MEF & $0,43 \%$ & 0,4493 & 1,5300 & 0,3055 & 2,2849 \\
\hline MPN & $7,56 \%$ & 0,4855 & 2,2556 & 0,5552 & 3,2964 \\
\hline OIL & $1,85 \%$ & 0,4474 & 1,3045 & 0,2315 & 1,9834 \\
\hline PPL & $9,05 \%$ & 0,2426 & 1,4754 & 0,3079 & 2,0259 \\
\hline PREH & $4,17 \%$ & 0,2178 & 2,0023 & 0,4954 & 2,7155 \\
\hline PTR & $19,73 \%$ & 0,4849 & 2,3746 & 0,5737 & 3,4332 \\
\hline RMAH & $-3,08 \%$ & 0,6105 & 1,3505 & 0,2089 & 2,1699 \\
\hline ROCE & $-1,77 \%$ & 0,1245 & 1,6519 & 0,3936 & 2,1701 \\
\hline RRC & $-28,72 \%$ & 0,0521 & 1,9941 & 1,0434 & 3,0896 \\
\hline SCD & $2,91 \%$ & 0,3032 & 1,7856 & 0,4190 & 2,5079 \\
\hline SNO & $11,14 \%$ & 0,5909 & 1,7304 & 0,4082 & 2,7295 \\
\hline SNP & $10,25 \%$ & 0,3114 & 3,1127 & 0,6735 & 4,0977 \\
\hline SOCP & $5,39 \%$ & 0,4506 & 1,2803 & 0,2155 & 1,9464 \\
\hline STZ & $0,20 \%$ & 0,0238 & 1,4763 & 0,3145 & 1,8146 \\
\hline $\mathrm{TBM}$ & $-12,87 \%$ & 0,3060 & 1,1498 & 0,0740 & 1,5297 \\
\hline TEL & $1,40 \%$ & 0,1423 & 3,8294 & 0,7370 & 4,7087 \\
\hline TGN & $12,62 \%$ & 0,2770 & 3,7775 & 0,7351 & 4,7896 \\
\hline TRP & $13,83 \%$ & 0,4108 & 1,9867 & 0,4864 & 2,8840 \\
\hline TUFE & $4,68 \%$ & 0,1668 & 1,8828 & 0,4661 & 2,5156 \\
\hline UAM & $0,44 \%$ & 0,4714 & 1,7521 & 0,4148 & 2,6384 \\
\hline UCM & $-13,15 \%$ & 0,4705 & 0,6561 & $-1,4353$ & $-0,3087$ \\
\hline VESY & $-3,27 \%$ & 0,7374 & 1,4980 & 0,3253 & 2,5607 \\
\hline VNC & $7,03 \%$ & 0,3748 & 1,5972 & 0,3738 & 2,3458 \\
\hline Median & $3,62 \%$ & 0,3728 & 1,9611 & 0,3793 & 2,7132 \\
\hline
\end{tabular}

* Average values for period 2007-2009 